\title{
PENINGKATAN KUALITAS CITRA CT-SCAN DENGAN PENGGABUNGAN METODE FILTER GAUSSIAN DAN FILTER MEDIAN
}

\author{
Sumijan', Pradani Ayu Widya Purnama², Syafri Arlis ${ }^{3}$ \\ 1,2,3 Universitas Putra Indonesia"YPTK” Padang \\ .Email: 1sumijan@upiyptk.ac.id, ${ }^{2}$ pradaniwidya@upiyptk.ac.id, ${ }^{3}$ syafri_arlis@upiyptk.ac.id
}

(Naskah masuk: 25-07-2018, diterima untuk diterbitkan: 24 Januari 2019)

\begin{abstract}
Abstrak
Perkembangan alat teknologi akuisisi citra medis, satu diantaranya adalah teknologi yang lazim disebut CT-scan. CT-Scan (Computed Tomography Scan) adalah prosedur untuk mendapatkan gambaran dari berbagai area kecil dari tulang termasuk tengkorak kepala dan otak. Citra hasil akuisisi atau rekaman CT-Scan dapat mebantu memperjelas adanya dugaan yang kuat tentang kelainan yang terjadi pada otak. Kualitas citra dapat dilakukan dengan proses mengubah citra menjadi citra baru sesuai kebutuhan, salah satu cara seperti fungsi transformasi, operasi matematis dan pemfilteran. Peningkatan kualitas citra CT-Scan diperlukan untuk objek keputusan medis yang mempunyai kualitas tidak baik, misalnya citra mengalami derau (noise), citra terlalu terang atau gelap, citra kurang tajam, dan kabur. Proses Peningkatan kualitas citra dapat dilakukan dengan menerapkan salah satu metode pemfilteran, untuk memperbaiki kualitas citra agar dihasilkan citra yang lebih baik dari citra aslinya. Metode gaussian filter untuk mengurangi noise speckle dan poisson pada citra otak pada CT-Scan. Pada citra noise gaussian, standar deviasi yang terbaik dalam mengurangi noise bernilai satu. Namun untuk citra noise speckle dan poisson nilai standar tidak dapat mengurangi noise tersebut. Hal ini dikarenakan standar deviasi adalah parameter dalam proses gaussian filter hanya dapat untuk noise Gaussian normal, untuk mengurangi noise sebaran tidak normal (non-linier) digunakan median filter. Kelemahan gaussian filter pada noise nilai parameter tidak stabil (non-linier) dapat diatasi pada filter median. Dari hasil penggabungan filter gaussian dan filter median filter dapat meningkatkan kualitas citra dan menguranggi noise lebih baik sebaran normal dan tidak normal.
\end{abstract}

Kata kunci: Filter Median \& Filter Gaussian, Citra CT-Scan, Noise speckle \& Poisson

\section{THE IMPROVEMENT QUALITY OF IMAGE CT-SCAN WITH COMBINING GAUSSIAN FILTER AND MEDIAN FILTER METHOD}

\begin{abstract}
The development of medical image acquisition technology tools, one of which is the technology commonly called CT scan. CT-Scan (Computed Tomography Scan) is a procedure to get a picture of various small areas of bone including the skull and brain. Image acquisition results or CT-Scan recordings can help clarify the existence of strong suspicions about abnormalities that occur in the brain. Image quality can be done by the process of changing the image into a new image as needed, one way such as the transformation function, mathematical operations and filtering. Increasing the quality of CT-Scan images is needed for medical decision objects that have poor quality, for example images experience noise (noise), images are too bright or dark, images are less sharp, and blurred. The process of improving image quality can be done by applying one of the filtering methods, to improve image quality to produce a better image than the original image. Gaussian filter method to reduce speckle and poison noise in brain images on CT scan. In the Gaussian noise image, the best standard deviation in reducing noise is one. However, for speckle noise images and standard poison values it cannot reduce the noise. This is because the standard deviation is a parameter in the Gaussian filter process that can only be used for normal Gaussian noise, to reduce the abnormal noise distribution (non-linear) the median filter is used. The weakness of the Gaussian filter on the noise value of an unstable (non-linear) parameter can be overcome in the median filter. From the results of combining the Gaussian filter and median filter, it can improve image quality and reduce noise better than normal and abnormal distribution.
\end{abstract}

Keywords: Median Filter \& Gaussian Filter, Image CT-Scan, Noise speckle \& Poisson 


\section{PENDAHULUAN}

Perkembangan peralatan teknologi akuisisi citra medis, salah satu diantaranya adalah teknologi yang lazim disebut CT-scan. CT-scan (Computed Tomography Scan) adalah prosedur untuk mendapatkan gambaran berbagai area kecil dalam tulang termasuk tengkorak kepala dan otak manusia. Citra hasil akuisisi atau rekaman CT-scan dapat mebantu memperjelas adanya dugaan yang kuat tentang kelainan yang terjadi pada otak, misalnya : gambaran lesi dari tumor, hematoma dan abses, pendarahan pada otak serta perubahan vaskuler berupa malformasi, naik turunnya vaskularisasi dan infark. $\boldsymbol{C T}$-Scan terdiri dari tiga bagian, pertama: Sistem Akuisisi Citra, Sistem Komputer dan Kendali, kedua: Stasiun Operasi, dan ketiga: Stasiun Pengamat. CT-Scan bekerja dalam sistem akuisisi citra terdapat dalam frame pipa dari mesin dan merupakan bagian sistem yang langsung berhadapan dengan pasien. Scanner terdiri atas sumber sinar-X, collimator, detektor, dan bagian akuisisi data. Akuisisi citra CT Scan otak umumnya dilakukan dalam bentuk 2 dimensi (2D) yang direkam dalam bentuk slice (irisan) dengan jarak tertentu antara slice satu terhadap slice lainnya. Pada setiap slice citra merepresentasikan keadaan otak pada posisi slice tersebut. Representasi inforasi visual adalah berupa variasi intensitas warna atau tingkat keabuan dari irisan otak dan objek lain (bila ada), seperti yang diperlihatkan oleh gambar 1.1 Gambar 1(a) memperlihatkan salah satu slice citra otak normal dan gambar 1.(b) merupakan slice citra otak yang tidak normal dan area berwarna putih didalam otak adalah area pendarahan.
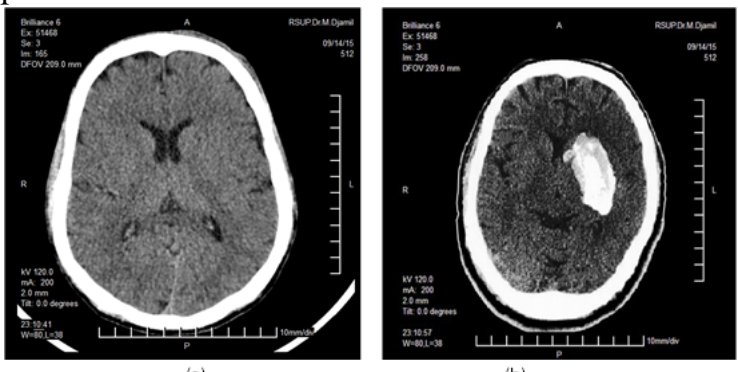

Gambar 1. (a). Citra Otak Normal, (b). Citra Otak Terjadi Pendarahan, Sumber : RSUP DR. M. Djamil Padang Sumatera Barat, 2015

Kualitas citra adalah proses merubah citra asli menjadi citra baru sesuai kebutuhan melalui beberapa cara seperti : menggunakan fungsi transformasi, operasi matematis dan pemfilteran. Kualitas citra diperlukan agar citra yang dijadikan objek penelitian mempunyai kualitas yang baik, sehingga terbebas dari citra mengalami derau (noise) saat pengiriman melalui saluran transmisi, citra terlalu terang/gelap, citra kurang tajam, kabur atau citra yang tidak berkualitas baik. Proses Peningkatan kualitas citra dapat dilakukan dengan menerapkan berbagai metode untuk menghasilkan citra yang lebih bagus dari citra sebelumnya salah satunya yaitu metode pemfilteran. Tujuan atama perbaikan kualitas citra adalah untuk mengolah citra agar citra yang dihasilkan menjadi lebih baik dari citra aslinya.

Beberapa penelitian sebelumnya yang telah menerapkan Filter seperti yang dilakukan oleh Julio et al, (2016), Filter Gaussian yaitu operator konvolusi yang digunakan untuk mengaburkan gambar dan untuk menghilangkan gangguan (noise), Peneliti berikutnya menyimpulkan bahwa keuntungan dari keakuratan estimasi dengan metode filter gaussian dapat diterapkan pada berbagai jenis aplikasi (Huang et al. 2015). Penelitian lain menyimpulkan dari hasil uji coba yang telah dilakukan memperlihatkan bahwa Filter Gaussian dapat memberikan perubahan yang lebih sesuai dengan akurasi filter dibandingkan dengan implementasi metode yang lain (Charalampidis 2016).

Penelitian Suganesh and Poovathy (2016), Filter Gaussian adalah metode terbaik untuk peningkatan kualitas citra hasil penginderaan yang kemudian dikompresi dengan ukuran yang relative lebih kecil. Yano and Kuroki (2016), dalam penelitiannya menjelaskan bahwa Filter Gaussian dapat melakukan penyaringan binomial secara paralel pada GPU (Graphical Processing Units) dengan akurasi yang tinggi. Yano and Kuroki (2016), menggunakan Filter Gaussian yang dikombinasikan dengan jaringan syaraf tiruan lebih efisien dalam mengembalikan data terdistorsi dan menghilangkan gangguan. Afshari, Gadsden, and Habibi, (2017), Filter Gaussian dapat digunakan meminimalkan kesalahan estimasi sekaligus mengurangi gangguan yang terjadi selama proses pemodelan sistem. Cabello, (2015), dari penelitian yang dilakukan dengan menggunakan FPGA kinerja Filter Gaussian jauh lebih cepat untuk proses penyaringan saat membaca gambar secara bersamaan. Hasil penelitian lain menunjukkan bahwa algoritma Filter Gaussian mampu mempertahankan kontras suatu gambar dan informasi warna dengan proses yang lebih cepat (Liu, Shang, and Chen 2016).

Penelitian ini menggabungkan Filter Gaussian dan Filter Median (Hybrid Filtering) untuk meningkatkan kualitas citra medis dengan cara mengurangi citra mengalami derau (noise) saat pengiriman melalui saluran transmisi, citra terlalu terang/gelap, citra kurang tajam, kabur atau citra yang tidak berkualitas baik yang terdapat pada citra CT-Scan.

\section{METODE PENELITIAN}

Tahapan penelitian terdiri dari input citra, cropping citra, melakukan konversi citra ke grayscale (keabuan), kemudian melakukan Filter Gaussian, dilanjutkan dengan filter median dan akhir dari tahap penelitian ini adalah hybrid filtering, dapat diperlihatkan pada gambar $2 \mathrm{sbb}$ :

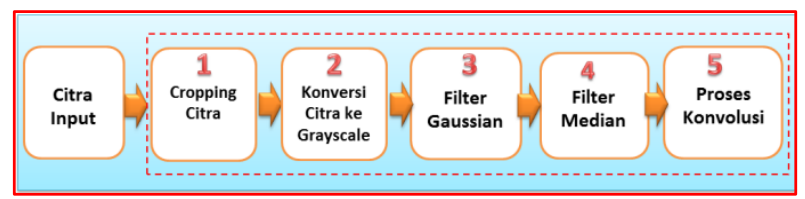

Gambar 2. Tahapan Kerangka Penelitian 


\subsection{Citra Input}

Citra input menggunakan dataset CT-Scan. CT-Scan untuk mendapatkan gambaran citra dari beberapa sudut kecil dari tulang tengkorak dan otak manusia. Pemeriksaan $\boldsymbol{C T}$-Scan memperjelas adanya dugaan kuat terjadinya kelainan pada tengkorak atau otak manusia. Dataset CT-Scan yang digunakan pada penelitian ini terbagi menjadi 2 Pasien yang terdiri dari 6-10 slice setiap pasien.

\subsection{Cropping Citra}

Proses cropping bertujuan untuk menghilngkan noise yang tidak perlu diluar obyek penelitian, menentukan citra dari obyek penelitian yang akan dianalisa dan diolah, dan mengperkecil ukuran citra $C T$ Scan asli agar dapat dengan mudah di olah dan dianalisa.

\subsection{Konversi Citra GrayScale}

Proses konversi dengan cara mengonversi citra berwarna ke bentuk citra berskala keabuan mengingat banyak pemrosesan citra yang bekerja pada skala keabuan. Namun, biasanya citra berskala keabuan perlu dilakukan konversi ke citra biner, biasanya beberapa operasi pengolahan citra dilakukan pada skala citra biner. Cara mengkonversi citra berwarna ke citra berskala keabuan. Citra berwarna dapat dikonversikan ke citra keabuan dengan rumus sbb:

$\mathrm{I}=\mathrm{a} \times \mathrm{R}+\mathrm{b} \times \mathrm{G}+\mathrm{c} \times \mathrm{B}, \quad \mathrm{a}+\mathrm{b}+\mathrm{c}=1$

dimana $\mathrm{R}$ adalah nilai skala merah, $\mathrm{G}$ nilai skala hijau, dan B nilai skala biru. Misalnya, sebuah piksel mempunyai nilai skala $R, G, B$ sebagai berikut: $R=50$, $\mathrm{G}=70, \mathrm{~B}=61$

Jika a, b, dan c pada Persamaan 2.1 dibuat sama, akan diperoleh hasil seperti berikut $: I=(50+70+60) /$ $3=60$

Diberikan contoh rumus yang digunakan untuk mengkonversikan dari citra berwarna ke skala keabuan yaitu:

$\mathrm{I}=0,2989 \times \mathrm{R}+0,5870 \times \mathrm{G}+0,1141 \times \mathrm{B}$

\subsection{Metode Filter Gaussianing}

Metode interpolasi linier adalah algoritma matematika dapat diterapkan menaksir titik harga tengahan melalui garis lurus pada setiap dua titik masukan yang berurutan. Interpolasi Linier adalah proses pembesaran skala citra yang dikerjakan di dalam obyek bitmap dan resolusi akan bertambah setelah proses pembesaran dilakukan pada citra masukan. Proses penambahan Piksel baru dilakukan dengan menyisipkan titik-titik tersebut diantara titik-titik yang nilainya telah ditetapkan langsung dari citra asli. Piksel yang ada di citra masukan berisi informasi intensitas warna R-G-B untuk menaksir intensitas warna dari piksel yang masih kosong pada citra obyek bitmap.
Proses awal Interpolasi Linier melakukan proses penyeleksian terhadap hasil citra dari screen capture sebagai sampel. Hasil citra screen capture dilakukan proses selanjutnya, dengan cara membaca resolusi citra masukan citra bitmap objek digunakan untuk mengetahui ukuran atau resolusi citra dengan melakukan pengukuran tinggi dan lebar piksel dari citra. Proses dilakukan setelah citra dilakukan pembesaran dahulu, kemudian menginputkan skala pembesaran dengan nilai dibuat variabel scale. Filter Gaussian tergolong sebagai filter lolos-rendah yang didasarkan pada fungsi Gaussian. Model dua dimensinya berupa:

$G(y \cdot x)=e^{-\frac{x^{2}+y^{2}}{2 \sigma^{2}}}$

Dalam hal ini, $\sigma$ adalah deviasi standar dan piksel pada pusat $(\mathrm{y}, \mathrm{x})$ mendapatkan bobot terbesar berupa 1 .

\subsection{Metode Filter Median}

Metode Filter median sangat berguna menghilangkan citra yang berkualitas buruk dimana kebanyakan nilai piksel ekstrim. Filter median dalam memproses suatu citra menggunakan sliding neighborhood, sliding neighborhood adalah operasi filter dengan menentukan nilai masing-masing piksel keluaran dengan memeriksa berkonvolusi/bertetangga $m \times n$ di sekitar piksel masukan yang bersangkutan. Filter median menata nilai-nilai piksel dalam satu konvolusi dan memilih nilai median sebagai hasil. Median filter adalah salah satu jenis low-pass filter, filter ini bekerja dengan cara mengganti nilai piksel pada citra asal dengan nilai median dari piksel konvolusinya. Dibandingkan dengan neighborhood averaging, filter ini lebih tidak sensitif terhadap perbedaan intensitas yang ekstrim. Pada filter median, suatu 'jendela' (window) memuat sejumlah piksel. Jendela digeser titik demi titik pada seluruh area citra. Pada setiap pergeseran dibuat jendela baru. Titik median dari jendela ini diubah dengan nilai median dari jendela tersebut. Pada penapis median, suatu 'jendela' (window) memuat sejumlah piksel. Jendela digeser titik demi titik pada seluruh daerah citra. Filter median sangat populer dalam pengolahan citra. Filter ini dapat dipakai untuk menghilangkan derau bintik-bintik. Nilai yang lebih baik digunakan untuk suatu piksel ditentukan oleh nilai median dari setiap piksel dan kedelapan piksel tetangga pada 8-ketetanggaan. Filter median dapat dipakai untuk menghilangkan derau dalam citra. Filter ini menggunakan nilai median piksel-piksel di dalam jendela sebagai keluaran $\mathrm{f}^{\wedge}$. Jadi, filter median dapat ditulis sebagai berikut:

$\hat{f}(y, x)=\operatorname{median}_{(p, q) \in S_{y x}}(g(p, q))$

Hasil dari filter median terlihat bahwa derau dapat dihilangkan, tetapi detail pada citra tetap dipertahankan. Namun, hal ini tentu saja didapat dengan tambahan beban komputasi "pengurutan". 


\subsection{Proses Konvolosi}

Konvolusi seringkali dilibatkan dalam operasi ketetanggaan piksel. Konvolusi pada citra sering disebut sebagai konvolusi dua-dimensi (konvolusi 2D). Konvolusi 2D didefinisikan sebagai proses untuk memperoleh suatu piksel didasarkan pada nilai piksel itu sendiri dan tetangganya, dengan melibatkan suatu matriks yang disebut kernel yang merepresentasikan pembobotan. Wujud kernel umumnya bujur sangkar, tetapi dapat pula berbentuk persegi panjang

Prosesnya dirumuskan sebagai berikut:

$$
\begin{aligned}
& g(y, x)=\sum_{p=-m^{2}}^{m^{2}} \sum_{q=-n^{2}}^{n^{2}} h\left(p+m^{2}+1, q+n^{2}+\right. \\
& \text { 1) } f(y-p, x-q)
\end{aligned}
$$

Dalam hal ini,

$\checkmark \mathrm{m} 2 \quad$ : separuh dari tinggi kernel $(\mathrm{m} 2=\operatorname{floor}(\mathrm{m} / 2))$,

$\checkmark$ n2 : separuh dari lebar kernel (n2 $=$ floor $(\mathrm{n} / 2))$,

$\checkmark$ floor : menyatakan pembulatan ke bawah, dan

$\checkmark$ h : menyatakan kernel, dengan indeks dimulai dari 1.

Secara umum, proses penapisan di kawasan ruang (space domain), sebagai alternatif di kawasan frekuensi, dilaksanakan melalui operasi konvolusi. Operasi ini dilakukan dengan menumpangkan suatu jendela (kernel) yang berisi angka-angka pengali pada setiap piksel yang ditimpali. Kemudian, nilai rerata diambil dari hasil-hasil kali tersebut. Khusus bila angka-angka pengali tersebut semua adalah 1, hasil yang didapat sama saja dengan filter pererataan.

\section{HASIL DAN PEMBAHASAN}

Penelitian ini bertujuan untuk memperbaiki citra yang mengalami gangguan atau noise. Untuk dapat mengetahui apakah sistem ini mampu mengurangi noise, maka citra yang diuji terlebih dahulu ditambah noise kemudian dilakukan pengurangan noise dan citra output dari proses pengurangan noise dibandingkan dengan citra awal yang belum ditambah noise. Perbandingan citra output dengan citra awal dapat dilihat secara kualitatif dan kuantitatif. Secara kualitatif sistem bisa dikatakan mampu mengurangi noise apabila citra output tampak lebih jelas dan noise berkurang dibanding citra input serta citra output terlihat mendekati citra awal yang belum ber-noise. Secara kuantitatif penilain pengurangan noise dihitung dengan MSE (Mean Signal Error) dan PSNR (Peak Signal to Noise Ratio). Noise berkurang apabila nilai MSE antara citra output dengan citra awal lebih kecil dibandingkan nilai MSE antara citra input ber-noise dengan citra awal serta nilai PSNR antara citra output dengan citra awal lebih besar dibandingkan nilai PSNR antara citra ber-noise dengan citra awal. Kualitas citra output semakin bagus saat nilai MSE semain kecil, PSNR semakin besar dan citra output terlihat lebih mendekati citra asli. Sistem pengurangan noise yang pada penelitian ini dibangun berdasarkan algoritma metode difusi nonlinear anisotropik. Untuk mendapatkan kualitas citra keluaran terbaik dari proses pengurangan noise, maka pada penelitian ini setiap citra ber-noise dilakukan beberapa kali pengujian terhadap sistem dengan memvariasikan nilai parameter algoritma sistem dari masing-masing pengujian dan setiap pengujian dilakukan beberapa kali iterasi.

\subsection{Secara Kualitatif Berdasarkan Penglihatan}

Dari semua percobaan yang dilakukan, didapatkan hasil pengurangan noise pada semua citra output. Secara kualitatif citra output yang berkurang noise tampak lebih jelas dibanding citra input dan noise yang mengganggu terlihat berkurang dan noise pada bagian tepi citra berkurang tanpa ada efek pengaburan.

Gambar 5. merupakan salah satu sampel yang mempelihatkan perbandingan kualitas citra input dengan citra output :
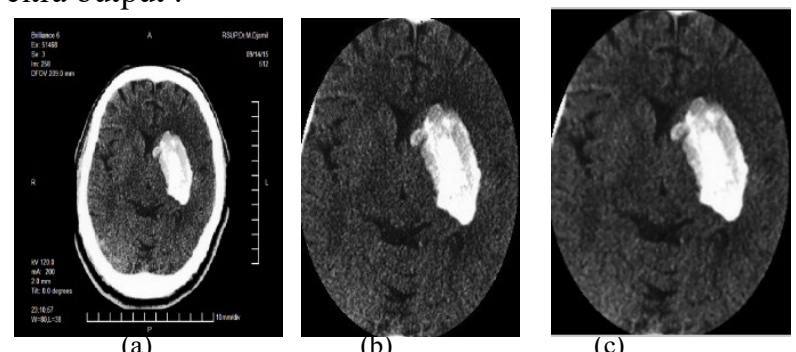

Gambar 5. (a) Citra awal, (b) citra input ber-noise gaussian (c) citra output hasil perbaikan

Penilaian kuantitatif dilakukan dengan membandingkan nilai MSE dan PSNR citra output dengan MSE dan PSNR citra input. Noise yang berkurang ditandai dengan nilai MSE output yang lebih kecil dibandingkan nilai MSE input dan kualitas citra mengalami peningkatan disaat nilai PSNR output lebih besar dibanding PSNR input

\section{a. Nilai MSE}

Secara kuantitatif didapatkan hasil nilai MSE citra output lebih kecil dibanding citra input dan PSNR citra output lebih besar dibandingkan citra input. Gambar 6 . memperlihatkan perbandingan MSE antara citra input dengan citra Pasien 1. output pada citra pasien 1.

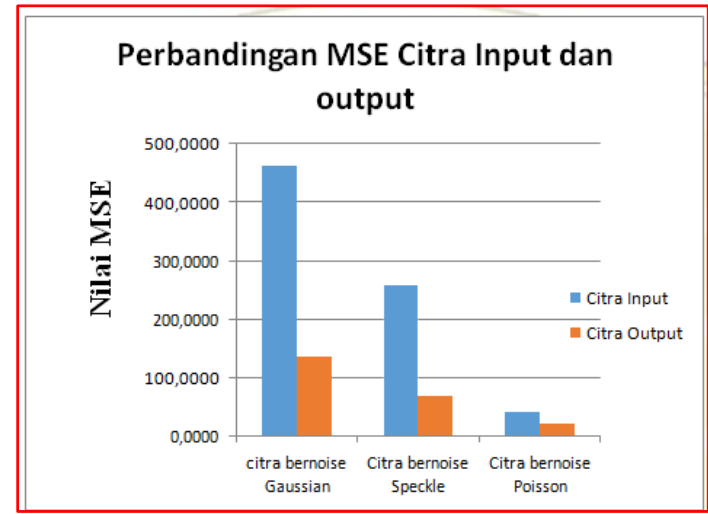

Gambar 6. Diagram perbandingan MSE citra output dengan citra input 
Dari gambar terlihat Nilai MSE citra output berkurang dibandingkan nilai MSE citra input pada semua jenis noise yang diberikan pada citra input. Hal tersebut menunjukkan bahwa sistem yang digunakan pada penelitian ini tidak hanya bisa mengurangi noise gaussian tetapi juga bisa mengurangi noise speckle dan poisson.

\section{b. Nilai PNSR}

semua percobaan yang dilakukan, didapatkan hasil nilai PSNR citra output lebih besar dibanding citra input. Hal ini menunjukkan citra output mengalami peningkatan kualitas dibanding citra input. Perbandingan MSE citra output dengan PSNR citra input dapat dilihat pada gambar 7. di bawah, data lengkap dari perbandingan PSNR citra input dengan citra output pada citra pasien 1

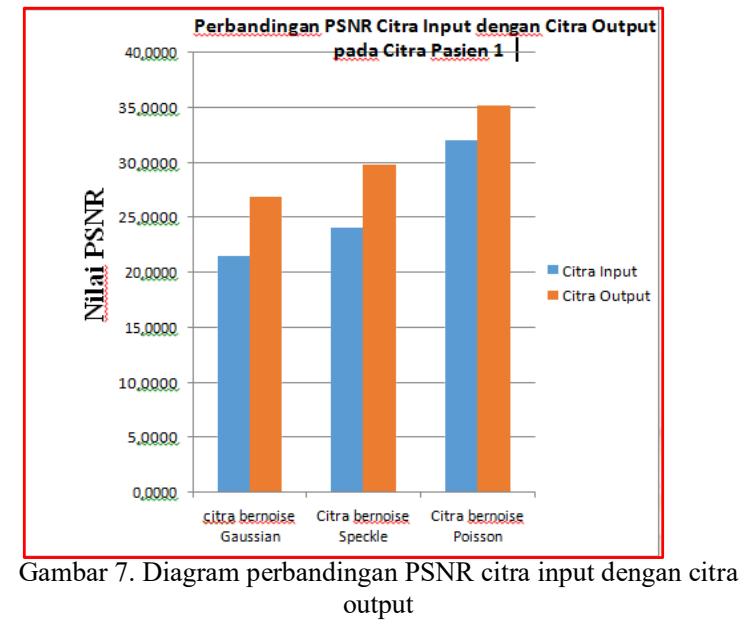

Perbandingan Penurunan nilai MSE dan kenaikan PSNR pada Masing-Masing Jenis Noise. Gambar 8. memperlihatkan rata-rata persentase penurunan nilai MSE dan kenaikan PSNR masing-masing jenis noise,

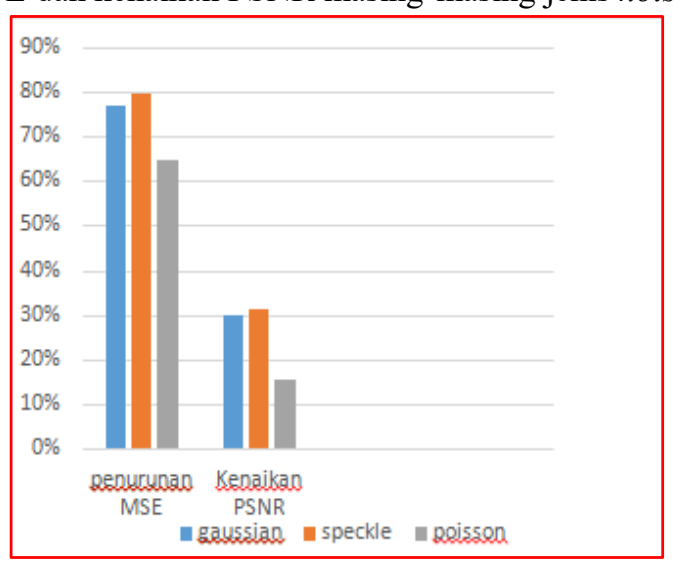

Gambar 8. Diagram rata-rata persentase penurunan MSE dan kenaikan PSNR seluruh citra pada masing-masing noise

Dari gambar di atas terlihat persentase penurunan MSE dan kenaikan PSNR terbesar dihasilkan pada noise speckle, hal itu menunjukkan pengurangan noise terbanyak terjadi pada noise speckle. Noise speckle lebih banyak berkurang dibanding noise gaussian dikarenakan noise speckle pada citra medis terdapat pada bagian citra saja sehingga lebih mudah dalam mengurangi noise.
Sedangkan noise gaussian terdistribusi pada seluruh bagian citra termasuk background citra sehingga noise yang berkurang lebih sedikit dibanding noise speckle. Noise poisson memiliki persentase pengurangan noise yang paling sedikit dibanding noise gaussian dan speckle, karena noise poisson memiliki intensitas noise yang sangat kecil sehingga pengurangan noise-nya juga kecil. Pengurangan noise yang banyak tidak mungkin terjadi pada noise dengan intensitas kecil, karena jika noise banyak berkurang pada noise dengan intensitas kecil menyebabkan noise akan hilang dan hal itu tidak mungkin terjadi karena sifat noise tidak bisa dihilangkan.

\subsection{Secara Visualusasi Berdasarkan Penglihatan}

Berikut table 1. menunjukan salah satu contoh perbandingan citra hasil filterisasi pada citra $C T$-Scan terhadap 8 pasien ketika nilai standar deviasi yang berbeda-beda sbb :

Tabel 1. Hasil Proses Filter Gaussian

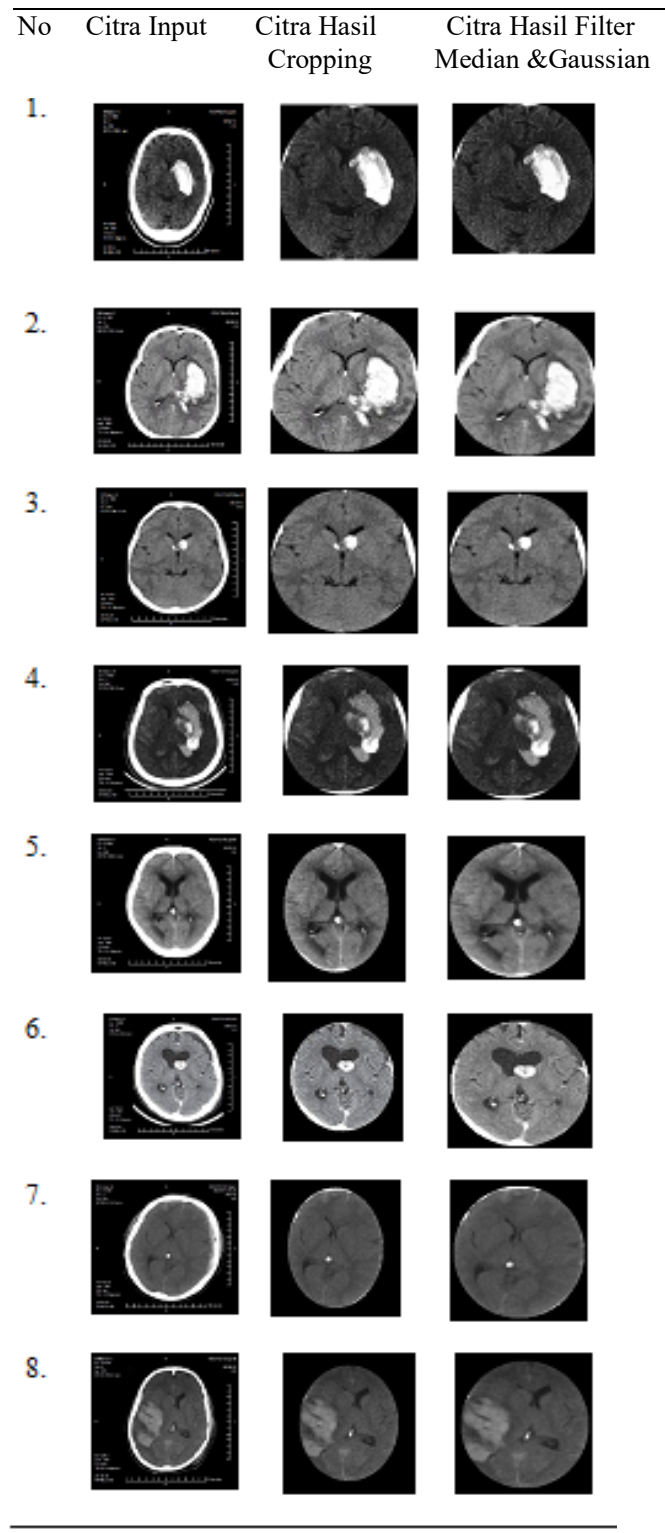


596 Jurnal Teknologi Informasi dan Ilmu Komputer (JTIIK), Vol. 6, No. 6, Desember 2019, hlm. 591-600

Standar deviasi yang menghasilkan MSE terkecil dari hasil difusi pada citra CT-Scan ber-noise speckle tergantung dari besar noise dan format citra inputnya. Pada format citra bmp citra input yang memilki noise yang lebih kecil (MSE kecil) adalah saat menggunakan standar deviasi bernilai dua. Sedangkan citra input yang ber-noise lebih besar yang menghasilkan MSE terkecil adalah saat standar deviasi yang digunakan bernilai tiga. Untuk format JPEG saat standar deviasi bernilai satu menghasilkan pengurangan noise yang lebih baik pada saat citra input memiliki noise yang lebih kecil. Untuk yang ber-noise lebih besar pengurangan noise yang lebih baik dihasilkan oleh standar deviasi bernilai dua. Dapat disimpulkan pada citra CT-Scan ber-noise speckle semakin besar noise citra, maka semakin besar pula standar deviasi yang dibutuhkan untuk proses difusi atau pengurangan noise yang lebih baik. Namun penilian besar kecilnya noise tergantung dari format citra. Tabel 1. memperlihatkan standar deviasi terbaik dalam mengurangi noise.

\section{i). Citra CT Scan 8 pasien diberi noise gaussian}

Nilai MSE dan PSNR citra ber-noise gaussian dengan citra asli adalah 420.6147 dan 21.9260 .

\section{a. Perbandingan MSE dan PSNR antara citra asli dengan citra setelah difusi dengan Kecepatan difusi 0,25}

Tabel 1. Perbandingan MSE dan PSNR antara citra asli dengan citra setelah difusi dengan Kecepatan difusi 0,25

\begin{tabular}{|c|c|c|c|c|c|c|}
\hline \multirow{2}{*}{$\begin{array}{l}\# P \\
\text { as }\end{array}$} & \multicolumn{2}{|c|}{ Standar deviasi $=1$} & \multicolumn{2}{|c|}{ Standar deviasi $=2$} & \multicolumn{2}{|c|}{ Standar deviasi $=3$} \\
\hline & $M S E$ & PSNR & MSE & $\begin{array}{c}P S N \\
R\end{array}$ & $M S E$ & $P S N R$ \\
\hline 1. & 187.7428 & 25.4292 & 182.6110 & 25.5495 & 181.1836 & 25.5836 \\
\hline 2. & 131.4510 & 26.9772 & 130.2791 & 27.0161 & 130.5391 & 27.0074 \\
\hline 3. & 111.0700 & 27.7088 & 112.5760 & 27.6503 & 114.6489 & 27.5711 \\
\hline 4. & 102.7676 & 28.0462 & 105.9951 & 27.9119 & 109.8746 & 27.7558 \\
\hline 5. & 99.6536 & 28.1799 & 104.0129 & 27.9939 & 109.6195 & 27.7659 \\
\hline 6. & 99.1259 & 28.2029 & 104.3260 & 27.9809 & 111.5757 & 27.6891 \\
\hline 7. & 34.4457 & 32.7934 & 105.9055 & 27.9156 & 114.7675 & 27.5666 \\
\hline 8. & 38.3115 & 32.3315 & 108.1752 & 27.8235 & 118.6550 & 27.4219 \\
\hline
\end{tabular}

b. Perbandingan MSE dan PSNR antara citra asli dengan citra setelah difusi dengan Kecepatan difusi 0,15

Tabel 2. Perbandingan MSE dan PSNR antara citra asli dengan citra setelah difusi dengan Kecepatan difusi 0,15

\begin{tabular}{|c|c|c|c|c|c|c|}
\hline \multirow{2}{*}{$\begin{array}{l}\# P \\
\text { as }\end{array}$} & \multicolumn{2}{|c|}{ Standar devias $i=1$} & \multicolumn{2}{|c|}{ Standar deviasi $=2$} & \multicolumn{2}{|c|}{ Standar deviasi $=3$} \\
\hline & $M S E$ & $P S N R$ & $M S E$ & $\begin{array}{c}P S N \\
R\end{array}$ & $M S E$ & $P S N R$ \\
\hline 1. & 230.4204 & 24.5396 & 223.6715 & 24.6687 & 221.7834 & 24.7055 \\
\hline 2. & 160.6974 & 26.1047 & 156.5304 & 26.2188 & 155.5545 & 26.2460 \\
\hline 3. & 129.5282 & 27.0412 & 128.1003 & 27.0893 & 128.4515 & 27.0774 \\
\hline 4. & 113.9213 & 27.5987 & 114.5967 & 27.5731 & 116.2423 & 27.5112 \\
\hline 5. & 105.6489 & 27.9261 & 107.8334 & 27.8373 & 110.8433 & 27.7177 \\
\hline 6. & 101.2212 & 28.1121 & 104.5968 & 27.9696 & 108.9014 & 27.7945 \\
\hline 7. & 99.0908 & 28.2045 & 103.3125 & 28.0233 & 108.8796 & 27.7953 \\
\hline 8. & 230.4204 & 24.5396 & 223.6715 & 24.6687 & 221.7834 & 24.7055 \\
\hline
\end{tabular}

c. Perbandingan MSE dan PSNR antara citra asli dengan citra setelah difusi dengan Kecepatan difusi 0,11

Tabel 3. Perbandingan MSE dan PSNR antara citra asli dengan citra setelah difusi dengan Kecepatan difusi 0,11

\begin{tabular}{|c|c|c|c|c|c|c|}
\hline$\# P a$ & \multicolumn{2}{|c|}{ Standar deviasi $=1$} & \multicolumn{2}{|c|}{ Standar deviasi $=2$} & \multicolumn{2}{|c|}{ Standar deviasi $=3$} \\
\hline$s$ & $M S E$ & $P S N R$ & $M S E$ & PSNR & $M S E$ & PSNR \\
\hline 1. & 259.0780 & 24.0305 & 252.0656 & 24.1497 & 250.1377 & 24.1830 \\
\hline 2. & 185.5511 & 25.4802 & 179.7147 & 25.6190 & 178.1800 & 25.6562 \\
\hline 3. & 147.9844 & 26.4626 & 144.4576 & 26.5674 & 143.8683 & 26.5851 \\
\hline 4. & 127.1134 & 27.1229 & 125.7021 & 27.1714 & 126.1478 & 27.1560 \\
\hline 5. & 114.8547 & 27.5633 & 115.0957 & 27.5542 & 116.6686 & 27.4953 \\
\hline 6. & 107.4106 & 27.8543 & 109.0232 & 27.7896 & 111.6234 & 27.6872 \\
\hline 7. & 102.8481 & 28.0428 & 105.5408 & 27.9306 & 109.2100 & 27.7822 \\
\hline 8. & 100.1474 & 28.1584 & 103.7193 & 28.0062 & 108.4220 & 27.8136 \\
\hline
\end{tabular}

\section{ii). Citra CT Scan 8 pasien diberi noise speckle}

Nilai MSE dan PSNR citra benoise speckle dengan citra asli 231.1841 dan 24.5252 .

a) Perbandingan MSE dan PSNR antara citra asli dengan citra setelah difusi dengan Kecepatan difusi 0,25

Tabel 4. Perbandingan MSE dan PSNR antara citra asli dengan citra setelah difusi dengan Kecepatan difusi 0,25

\begin{tabular}{lcrcrcr}
\hline$\# \boldsymbol{P}$ & \multicolumn{2}{c}{ Standar deviasi $=\mathbf{I}$} & \multicolumn{2}{c}{ Standar deviasi $=\mathbf{2}$} & \multicolumn{2}{c}{ Standar deviasi=3 } \\
\cline { 2 - 7 } as & $\boldsymbol{M S E}$ & $\boldsymbol{P S N R}$ & $\boldsymbol{M S E}$ & $\boldsymbol{P S N R}$ & $\boldsymbol{M S E}$ & $\boldsymbol{P S N R}$ \\
1. & 108.216 & 27.8219 & 103.0856 & 28.0328 & 102.114 & 28.0739 \\
2. & 78.0580 & 29.2406 & 74.8541 & 29.4226 & 75.4247 & 29.3897 \\
3. & 67.9214 & 29.8447 & 66.4134 & 29.9422 & 68.7618 & 29.7913 \\
4. & 64.7657 & 30.0513 & 64.4701 & 30.0712 & 68.5724 & 29.8033 \\
5. & 64.6608 & 30.0584 & 65.2815 & 30.0169 & 71.0940 & 29.6465 \\
6. & 66.1956 & 29.9565 & 67.4175 & 29.8771 & 74.9240 & 29.4186 \\
7. & 98.6725 & 28.2228 & 102.9230 & 28.0397 & 108.6651 & 27.8039 \\
8. & 98.0197 & 28.2517 & 102.8892 & 28.0411 & 109.5771 & 27.7676 \\
\hline
\end{tabular}

b) Perbandingan MSE dan PSNR antara citra asli dengan citra setelah difusi dengan Kecepatan difusi 0,15

Tabel 5. Perbandingan MSE dan PSNR antara citra asli dengan citra setelah difusi dengan Kecepatan difusi 0,15

\begin{tabular}{|c|c|c|c|c|c|c|}
\hline \multirow{2}{*}{$\begin{array}{c}\# P \\
\text { as }\end{array}$} & \multicolumn{2}{|c|}{ Standar deviasi $=1$} & \multicolumn{2}{|c|}{ Standar deviasi $=2$} & \multicolumn{2}{|c|}{ Standar deviasi $=3$} \\
\hline & $M S E$ & $P$ PSNR & $M S E$ & $P S N R$ & $M S E$ & $P$ PSNR \\
\hline 1. & 131.4650 & 26.9767 & 125.8584 & 27.1660 & 124.5430 & 27.2116 \\
\hline 2. & 93.9549 & 28.4356 & 89.1392 & 28.6641 & 88.6358 & 28.6887 \\
\hline 3. & 77.3787 & 29.2786 & 73.9731 & 29.4741 & 74.6755 & 29.4330 \\
\hline 4. & 69.4709 & 29.7468 & 67.3658 & 29.8804 & 69.3777 & 29.7526 \\
\hline 5. & 65.7903 & 29.9832 & 64.7463 & 30.0527 & 68.0374 & 29.8373 \\
\hline 6. & 64.4506 & 30.0725 & 64.1590 & 30.0922 & 68.7630 & 29.7913 \\
\hline 7. & 64.5715 & 30.0644 & 64.7996 & 30.0491 & 70.6295 & 29.6749 \\
\hline 8. & 65.1059 & 30.0286 & 64.7346 & 30.0534 & 70.7547 & 29.6672 \\
\hline
\end{tabular}

c) Perbandingan MSE dan PSNR antara citra asli dengan citra setelah difusi dengan Kecepatan difusi 0,11 
Tabel 6. Perbandingan MSE dan PSNR antara citra asli dengan citra setelah difusi dengan Kecepatan difusi 0,11

\begin{tabular}{|c|c|c|c|c|c|c|}
\hline$\# P$ & \multicolumn{2}{|c|}{ Standar deviasi $=1$} & \multicolumn{2}{|c|}{ Standar deviasi $=2$} & \multicolumn{2}{|c|}{ Standar deviasi $=3$} \\
\hline as & $M S E$ & $\overline{P S N R}$ & $\overline{M S E}$ & $\overline{P S N R}$ & $M S E$ & $\overline{P S N R}$ \\
\hline 1. & 146.9067 & 26.4944 & 141.4722 & 26.6581 & 140.1134 & 26.7000 \\
\hline 2. & 107.5501 & 27.8487 & 101.9888 & 28.0793 & 101.0008 & 28.1216 \\
\hline 3. & 87.3620 & 28.7516 & 82.8070 & 28.9841 & 82.6968 & 28.9899 \\
\hline 4. & 76.3200 & 29.3384 & 72.8887 & 29.5382 & 73.7822 & 29.4853 \\
\hline 5. & 70.1011 & 29.7076 & 67.7185 & 29.8577 & 69.6443 & 29.7359 \\
\hline 6. & 66.7042 & 29.9233 & 65.1595 & 30.0250 & 68.1258 & 29.8317 \\
\hline 7. & 65.1513 & 30.0256 & 64.1587 & 30.0922 & 68.1451 & 29.8305 \\
\hline 8. & 64.7594 & 30.0518 & 64.1255 & 30.0945 & 69.1500 & 29.7669 \\
\hline
\end{tabular}

\section{iii). Citra CT Scan 8 Pasien diberi noise Poisson}

Nilai MSE dan PSNR citra bernoise Poisson dengan citra asli adalah 42.4268 dan 31.8884

a) Perbandingan MSE dan PSNR antara citra asli dengan citra setelah difusi dengan Kecepatan difusi 0,25

Tabel 7. Perbandingan MSE dan PSNR antara citra asli dengan citra setelah difusi dengan Kecepatan difusi 0,25

\begin{tabular}{|c|c|c|c|c|c|c|}
\hline$\# P$ & \multicolumn{2}{|c|}{ Standar deviasi $=1$} & \multicolumn{2}{|c|}{ Standar deviasi $=2$} & \multicolumn{2}{|c|}{ Standar deviasi $=3$} \\
\hline as & $M S E$ & $\overline{P S N R}$ & $\overline{M S E}$ & $\overline{P S N R}$ & $\overline{M S E}$ & $\overline{P S N R}$ \\
\hline 1. & 20.4037 & 35.0677 & 20.3958 & 35.0694 & 20.7354 & 34.9977 \\
\hline 2. & 18.4305 & 35.5094 & 18.9798 & 35.3819 & 20.3663 & 35.0757 \\
\hline 3. & 20.3151 & 35.0866 & 21.3613 & 34.8685 & 23.9896 & 34.3646 \\
\hline 4. & 26.0846 & 34.0010 & 25.8288 & 34.0438 & 25.8424 & 34.0415 \\
\hline 5. & 20.1294 & 35.1265 & 20.1134 & 35.1299 & 20.5430 & 35.0382 \\
\hline 6. & 18.2938 & 35.5418 & 18.6121 & 35.4668 & 19.6098 & 35.2401 \\
\hline 7. & 18.2961 & 35.5412 & 18.9698 & 35.3842 & 20.6333 & 35.0191 \\
\hline 8. & 19.2186 & 35.3276 & 20.2063 & 35.1099 & 22.5852 & 34.6266 \\
\hline
\end{tabular}

b) Perbandingan MSE dan PSNR antara citra asli dengan citra setelah difusi dengan Kecepatan difusi 0,15

Tabel 8. Perbandingan MSE dan PSNR antara citra asli dengan citra setelah difusi dengan Kecepatan difusi 0,15

\begin{tabular}{|c|c|c|c|c|c|c|}
\hline$\# P$ & Standar & vias $i=1$ & $\overline{\text { Standa }}$ & vias $i=2$ & Standar & evias $i=3$ \\
\hline as & MSE & $\overline{P S N R}$ & $M S E$ & $\overline{P S N R}$ & $M S E$ & $P S N R$ \\
\hline 1. & 23.5875 & 34.4380 & 23.3977 & 34.4731 & 23.4868 & 34.4566 \\
\hline 2. & 18.7648 & 35.4314 & 18.9575 & 35.3870 & 19.6752 & 35.2256 \\
\hline 3. & 18.2916 & 35.5423 & 18.9000 & 35.4002 & 20.4263 & 35.0629 \\
\hline 4. & 19.4639 & 35.2725 & 20.4675 & 35.0541 & 22.8805 & 34.5701 \\
\hline 5. & 26.0846 & 34.0010 & 25.8288 & 34.0438 & 25.8424 & 34.0415 \\
\hline 6. & 20.1294 & 35.1265 & 20.1134 & 35.1299 & 20.5430 & 35.0382 \\
\hline 7. & 18.2938 & 35.5418 & 18.6121 & 35.4668 & 19.6098 & 35.2401 \\
\hline 8. & 18.2961 & 35.5412 & 18.9698 & 35.3842 & 20.6333 & 35.0191 \\
\hline
\end{tabular}

c) Perbandingan MSE dan PSNR antara citra asli dengan citra setelah difusi dengan Kecepatan difusi 0,11

Tabel 9. Perbandingan MSE dan PSNR antara citra asli dengan citra setelah difusi dengan Kecepatan difusi 0,11

\begin{tabular}{|c|c|c|c|c|c|c|}
\hline$\# P$ & Standar & evias $i=1$ & Standar & viasi $=2$ & Standar & vias $i=3$ \\
\hline as & MSE & PSNR & MSE & PSNR & MSE & $P S N R$ \\
\hline 1. & 26.0846 & 34.0010 & 25.8288 & 34.0438 & 25.8424 & 34.0415 \\
\hline 2. & 20.1294 & 35.1265 & 20.1134 & 35.1299 & 20.5430 & 35.0382 \\
\hline 3. & 18.2938 & 35.5418 & 18.6121 & 35.4668 & 19.6098 & 35.2401 \\
\hline 4. & 18.2961 & 35.5412 & 18.9698 & 35.3842 & 20.6333 & 35.0191 \\
\hline 5. & 19.2186 & 35.3276 & 20.2063 & 35.1099 & 22.5852 & 34.6266 \\
\hline 6. & 20.1294 & 35.1265 & 20.1134 & 35.1299 & 20.5430 & 35.0382 \\
\hline 7. & 18.2938 & 35.5418 & 18.6121 & 35.4668 & 19.6098 & 35.2401 \\
\hline 8. & 18.2961 & 35.5412 & 18.9698 & 35.3842 & 20.6333 & 35.0191 \\
\hline
\end{tabular}

Nilai standar deviasi yang menghasilkan MSE terkecil pada proses difusi citra ber-noise poisson tergantung pada citra yang digunakan. Nilai standar deviasi terbaik dalam proses difusi citra ber-noise poisson dari hasil yang didapatkan pada percobaan yang dilakukan adalah sebagai berikut:

a. Citra 3 Pasien CT-Scan : pasien 1, 2, dan 6 proses filtering pada semua sampel citra CT menghasilkan MSE terbesar saat menggunakan standar deviasi bernilai satu.

b. Citra 5 Pasien $C T$-Scan : pasien 3, 4, 5, 7 dan 8 : proses filtering sampel citra tersebut menghasilkan MSE terkecil saat menggunakan standar deviasi bernilai satu.

Dengan menggabungkan algoritma filtering gaussian dan median yang digunakan pada penelitian ini, pertama kali dilakukan proses filter dengan gaussian filter, kemudian dengan median filter dan dilakukan proses konvolusi. Penelitian ini melkukan proses filter dengan gaussian filter dan median filter dapat mengurangi noise speckle dan poisson pada citra CTScan. Pada citra ber-noise gaussian, standar deviasi yang terbaik dalam mengurangi noise adalah saat bernilai satu. Namun pada citra ber-noise speckle dan poisson nilai standar yang terbaik tidak stabil, tergantung dari citra yang digunakan. Hal ini dikarenakan standar deviasi adalah salah satu parameter dalam proses gaussian filter dan median filter. Untuk memperoleh kestabilan dalam mengurangi noise gaussian filter lebih baik digunakan pada noise sebaran normal (gaussian) sedang median filter untuk sebaran tidak normal (non-linier). Jadi ketika dilakukan filter dengan gaussian filter pada noise selain gaussian, nilai parameter dari gaussian filter tidak akan stabil dalam mengurangi noise. Dari semua hasil yang didapatkan noise hanya dapat berkurang dan tidak hilang keseluruhan. Hal ini dikarenakan sifat noise yang hanya bisa dikurangi dan mustahil untuk dihilangkan, dengan median filter kelemahan gaussian filter dapat diatasi sehingga hasil konvolusi dapat meningkatkan kulitas citra pada CT-Scan.

\section{KESIMPULAN}

1. Citra ber-noise gaussian membutuhkan waktu yang lama dalam pengurangan noise dibandingkan citra ber-noise speckle dan poisson. Hal ini dikarenakan citra ber-noise gaussian memiliki noise yang tersebar keseluruh citra termasuk background citra, sehingga dibutuhkan waktu yang lama dalam menyebarkan noise-nya.

2. Filter median dapat mengatasi kelemahan dari gaussian filter sehingga diperoleh hasil pengurangan noise yang lebih baik dan stabil, dari proses median filter yang dilakukan pertama kali dalam proses filter telah disesuaikan dengan jenis noise.

3. Proses filter yang dilakukan pada citra ber-noise gaussian dan median standar deviasi terbaik dalam mengurangi noise adalah saat bernilai satu. Rata- rata 
persentase penurunan MSE citra ber-noise gaussian dan median saat standar deviasi bernilai satu adalah $77,26 \%$, sedangkan saat standar deviasi bernilai dua rata- rata persentase penurunan MSE hanya 76,29\% dan bernilai tiga hanya $64,66 \%$. Pada citra ber-noise speckle dan poission standar deviasi terbaiknya tergantung dari jenis citra, ukuran dan besarnya noise citra yang digunakan.

\section{DAFTAR PUSTAKA}

AFSHARI, H H, S A GADSDEN, and S HABIBI. 2017. Signal Processing Author 'S Accepted Manuscript Gaussian Filters for Parameter and State Recent Trends To Appear in: Signal Processing Gaussian Filters for Parameter and State Estimation: A General Review of Theory and Recent Trends. Elsevier. http://dx.doi.org/10.1016/j.sigpro.2017.01.001.

ARIPIN, SOEB, and HERY SUNANDAR. 2017. "Perancangan Aplikasi Perbaikan Citra Pada Hasil Screenshot Menggunakan Metode Interpolasi Linier 1." (October).

CABELLO, FRANK. 2015. "W; O _ Wll Rllllllllill â€TM Entil IIIII III." : 28-33.

CHARALAMPIDIS, DIMITRIOS. 2016. "Recursive Implementation of the Gaussian Filter Using Truncated Cosine Functions." IEEE Transactions on Signal Processing 64(14): 3554-65.

HUANG, YULONG, YONGGANG ZHANG, XIAOXU WANG, and LIN ZHAO. 2015. "Gaussian Filter for Nonlinear Systems with Correlated Noises at the Same Epoch." Automatica 60: 122-26.

JULIANA, AJI, and AGUNG TRIAYUDI. 2014. "Implementasi Morphological Filtering Untuk Penajaman Citra Cctv." Protekinfo 1(September): 2-6.

JULIO, R. OLIVEIRA, LEONARDO B. SOARES, E. A.C. COSTA, and SERGIO BAMPI. 2016. "Energy-Efficient Gaussian Filter for Image Processing Using Approximate Adder Circuits.” In Proceedings of the IEEE International Conference on Electronics, Circuits, and Systems, , 450-53.

LIU, CHANG, ZHAOWEI SHANG, and QIAOSONG CHEN. 2016. "An Adaptive Tone Mapping Algorithm Based on Gaussian Filter." : 0-5.

NUGROHO, HENDRO. 2017. "Image Enhancement Pada Screen Capture CCTV Dengan Menggunakan Metode Histogram Ekualisasi.” 2(2): 99-106.

SEDDIK, HASSENE, SONDES TEBBINI, and EZZEDDINE BEN BRAIEK. 2014. "Intelligent Automation \& Soft Computing Smart Real Time Adaptive Gaussian Filter Supervised Neural Network for Efficient Gray Scale and RGB Image De-Noising." Intelligent Automation and Soft Computing 20(3): 347-64. http://dx.doi.org/10.1080/10798587.2014.888242.

SUGANESH, V, and J FLORENCE POOVATHY. 2016. "Filtering of Gaussian Filter Based Embedded
Enhancement Technique for Compressively Sensed Images." : 2177-81.

SUMIJAN, M. S., HARLAN, J., \& WIBOWO, E. P. 2017. Hybrids Otsu method, Feature region and Mathematical Morphology for Calculating Volume Hemorrhage Brain on CT-Scan Image and 3D Reconstruction. Telkomnika, 15(1), 283-291.

SUMIJAN, S., YUHANDRI, Y., \& BOY, W. (2016). Detection and Extraction of Brain Hemorrhage on the CT-Scan Image using Hybrid Thresholding Method. UPI YPTK Journal of Computer Science and Information Technology, 1(1).

SWAMINATHAN, R, PRIYA JHA, ASIF IQBAL, and MANOJ WADHWA. 2013. "Efficient Satellite Image Enhancement Technique Based On Filtering And Interpolation Methods.” 2(7): 1677-82.

Yano, Takahiro, and Yoshimitsu Kuroki. 2016. "Fast Implementation of Gaussian Filter by Parallel Processing of

SETIANINGSIH, CASI, SITI NURHAYATI, dan RIDWAN. 2011. "Medical Imaging". Jurusan Teknik Elektro Institut Teknologi Telkom Bandung.

HAMA, SHOKHAN MAHMOUD dan MUZHIR SHABHAN AL-ANI. 2014. Medical Image Based on Efficient Approach for Adaptive Anisotropic Diffusion. International Journal of Advances in Engineering \& Technology, ISSN : 22311963

WEERATUNGA, S. K. DANC. KAMATH. 2003. A Comparison of PDE based Non- Linear Anisotropic Diffusion Techniques for Image Denoising. Lawrence Livermore National Laboratory Technical Information Department's Digital Library.

MALATHI, K dan R. NEDUNCHELIAN. 2014. " Comparison of Various Noises and Filters for Fundus Images Using pre-Processing Techniques". Bioinformatics, ISSN 0975-6299.

SUTOYO, T et al. 2009. Teori Pengolahan Citra Digital. Yogyakarta: Penerbit Andi.

OCEANDRA, M. HAKIKI. 2013. "Pengurangan Noise pada Citra Digital Menggunakan Metode Statistik mean, median, Kombinasi dan Rekursif Filter". Fakultas Sains dan Teknologi, Universitas Islam Negeri Sultan Syarif kasim Riau Pekanbaru.

PRIMAYUNITA, FITRI , AGUS ZAINAL ARIFIN, dan ANNY YUNIARTI. "Implementasi Metode Klasifikasi Fuzzy C-Means Menggunakan Algoritma Multiscale Diffusion filtering”. Teknik Informatika, Fakultas Teknologi Informasi, Institut Teknologi Sepuluh Nopember.

HUMAIRA dan RASYIDAH. 2011. "Analisis Pengaruh Noise Terhadap Deteksi Wajah Manusia pada Citra Berwarna menggunakan Fuzzy”. Poli Rekayasa, Vol 6, No 2, ISSN 1858-3709.

GILBOA, GUY, NIR SOCHEN, dan YEHOSHUA Y. ZEEVI. 2002. Forward-and- Backward Diffusion Processes for Adaptive Image Enhancement and Denoising. IEEE Transactions on Image Processing, Vol 11, NO.7. 
IRYANTO, F. FRISTELLA, dan P. H. GUNAWAN. 2016. Pendekatan Numerik pada Model Isotropic dan Anisotropic Diffusion untuk Mendeteksi Tepi pada Pengolahan Citra. Ind. Journal on Computing Vol 1, Issue. 2, ISSN 2460-9056.

SEBATUBUN, MARIA MEDIATRIX. 2016. Peningkatan Kualitas Citra X-Ray Paru- Paru Menggunakan Contrast Limited Adaptive Histogram Equalization dan gaussian filter. Seminar Riset Teknologi Informasi (SRITI).

WEICKERT, JOACHIM. 2001. Anisotropic Diffusion in Image Processing. Denmark : B. G. Teubner Stuttgart.

PERONA, PIETRO dan JITENDRA MALIK. 1990. Scale-Space and Edge Detection Using Anisotropic Diffusion. IEEE Transactions on Pattern Analysis and Machine Intelligence, Vol 12, NO. 7.

SMOLKA, BOGDAN. 2002. On The Application of The Forward and Backward Diffusion Scheme for Image Enhancement. Journal of Medical Informatics \& Technologies vol.3, ISSN 1642-6037.

BOOMGAARD, REIN VAN DEN. TT. “Algorithms for Non-Linear Diffusion Matlab in a Literate Programming Style". Netherlands : Intelligent Sensory Information Systems University of Amsterdam.

WIJANARTO. 2009. Restorasi Citra Digital dengan Algoritma Inpainting. Techno.Com, Vol 8, No.1. 
Halaman ini sengaja dikosongkan 